\title{
Developing the Learning Media Video Tutorial of Ula- Ula Lembing Dance Web-Based Learning on Cultural Arts Subjects at SMA Negeri 2 Kejuruan Muda
}

\author{
Pilar Kuncoro AR ${ }^{1}$ Samsidar Tanjung ${ }^{2}$ Mursid $^{3}$ \\ ${ }^{1}$ Teknologi Pendidikan, Universitas Negeri Medan, Sumatera Utara, Indonesia \\ ${ }^{2}$ Teknologi Pendidikan, Universitas Negeri Medan, Sumatera Utara, Indonesia \\ ${ }^{3}$ Teknologi Pendidikan, Universitas Negeri Medan, Sumatera Utara, Indonesia \\ *Corresponding author.Email: pilar.kuncoro1993@gmail.com, samsisdartanjung55@gmail.com, \\ mursid.tp@gmail.com
}

\begin{abstract}
This study aims to: (1) produce proper learning by using Web Learning based Ula-Ula Lembing Dance Tutorial Video as dance learning in arts and culture subjects based on the quality criteria of the learning media used, (2) to find out that the Web Learning based Ula-Ula Lembing Dance Tutorial is used effectively for class X students of SMA Negeri 2 Kejuruan Muda.This type of research is developing the Borg and Gall product development model of Dick and Carey's learning design model. The object of this research is grade X students. The research instruments are objective tests, practical tests and learning design experts, media and materials. The data analysis technique used is descriptive statistics. The result of the study showed: (1) the expert test was very good qualification $(93,13 \%)$, (2) the learning design expert qualifications were very good (93,13\%), (3) the test media learning expert qualifications were very good (93,75\%), (4) individual qualification trials are very good $(95,16 \%)$, (5) small group trials of very good qualifications $(96,01 \%)$, (6) field trials are limited to very good qualifications $(96,12 \%)$, and is suitable for use in the process of learning senior high school students. The result of hypothesis testing prove that there are significant differences between student learning outcomes learned by using media products with student learning outcomes learned without using media product. This is indicated by the results of data processing obtained by $\mathrm{t}$-count $=4,782>$ $\mathrm{t}$ table $=1,679$, with $\mathrm{dk}=9$ at the significance level $\alpha=0.05$. It was concluded that the group learning outcomes of students who were taught using web learnin based Ula-Ula Lembing Dance tutorial video product were 82,3\% higher than the group of students who were taught without learning media product of 80,0 .
\end{abstract}

Keywords: Learning media, Tutorial video, Web learning.

\section{INTRODUCTION}

The development of science and technology has brought a very significant change to various dimensions of human life, both in economic, social, cultural and educational, therefore so that education does not lag behind, the development of science and technology is necessary to make adjustments. In addition, the development of science and technology is increasingly encouraging renewal efforts in the use of technological results in learning process. The use of media is very important in learning process in school, because it helps the achievement of learning goals. The preparation of learning media becomes one of the educator responsibilities and it is considered important to increase the interest in student learning activity, teacher presence to aim the learning activities, textbook as information and other media is also necessary toimprove student motivation as real form of learning activity, without interaction of student and media, learning process will never happen.Based on the finding in art and culture lesson in dance art material in Kejuruan Muda State 2 High School, through initial research conducted by researcher shows that: (1) the implementation of learning media which is less developing the student creativity through the implementation of learning sources in learning, (2) the use of multimedia in teaching and learning process is not yet maximal, (3) low activities of students in learning, (4) teaching materials that are still difficult to 
find in the library, (5) inadequate practice room laboratory facilities, (6) learning result (subject score) in the form of task/practice or exercise is generally low. Beside the constraint above, there are also other problems related to the learning process cited from special interview with art and culture Teacher which was conducted in December 2018 is concluded that, during this time, subject is mostly run with lecture method. The practice is conducted by the Teacher first, then followed together with the students. From this, researcher find out the cause of lack of goals delivery in the learning process. Dance art lesson is one of the materials taught in Art and Culture subject especially to students of grade $\mathrm{X}$, where the learning which is understanding about local cultural wisdom. According to the geographical location, State 2 High School is located in Aceh Tamiang Regency, from Aceh province is taken as an example of a regional dance. One of them is Ula-Ula Lembing Dance from Aceh Tamiang Regency. In this thing, researcher made a development of learning about that Dance. This dance is one of thelocal ancestral cultural heritage that must be preserved. Every teacher and student find difficulties in art and culture lesson especially in Aceh Tamiang Dance because of the limitedness in delivering good teaching materials, therefore, researcher had idea to make Web Learning based Tutorial Video of Ula-Ula Lembing Dance to make this learning material easy to deliver, practical, and easy to understand, also easy to be accessed by students anytime and anywhere according to their needs. Dance Art learning will be more interesting if it is implemented using current technology media, such as the use of Tutorial Video in web learning based Art learning which ease the student in the teaching and learning process, but the limitedness of competency owned by teachers in implementing learning with technology is still low, so that the learning process is less interesting.

\section{METHOD}

This research uses Borg and Gall method. In the initial stage, before further develpment, manual design was validated by material experts. Next, small group trial was conducted to find out receptivity of users towards the products. Next, validation was conducted by one media expert and one material expert, to find out the suitability level. Product effectiveness test was conducted in experiment research scheme, in two classes, experimental class treated with Web Learning based video media, and control class treated without Web Learning based tutorial video.

\section{RESULTS}

The manual of learning which is developed is assessed by material expert and media expert. Learning material expert validation was conducted to find out the content appropriateness $(94,27 \%)$ and presentation appropriateness $(91,67 \%)$. Media expert validation was conducted to find out the development design aspect of web learning based Ula-Ula Lembing tutorial video. Result of media expert validation obtained assessment average of $93,75 \%$. This research was conducted in Kejuruan Muda State 2 High School with 1 class. In the research to be conducted, the data is obtained fromstudent learning result from experimental class and control class. The data analysis technique used is to analyze the data by illustrating the collected data as its original without any meaning to make conclusion for public or for generalization.

The result of small group trial on Web Learning based tutorial video which is developed, shows that media is appropriate in five assessment aspects which includes aspect of guidance and information with percentage score of $94,44 \%$, media material aspect with percentage score of $96,24 \%$, design aspect, evaluation aspect with percentage score of $95,56 \%$, design and media facility aspect with percentage score of $96,67 \%$ and pedagogic effect aspect with percentage score of $96,0 \%$. This indicates that interactive learning media developed can fulfill the demand of learning necessity.The hypothesis testing in this research was conducted by using t-test formula.T-testis conducted to find out the developement effectiveness of Web Learning based tutorial video mediato improve the learning result of grade $\mathrm{X}$ students on Kejuruan Muda State 2 High School.Based on the calculation result was obtained the rate of Tcount< Ttable $=1,679$. Based on that result, then Ho and ha is accepted ot in other word there is significant difference between learning result of early childhood in experimental class and control classin significance level of $5 \%$. Therefore, the learning result of students who are taught with Web Learning based tutorial video media have differences.

\section{DISCUSSION}

The result of experiment shows that students who were treated with web learning based tutorial video media can learn better in learning the dance skills in art and culture subject. This research supports the research finding of mehmet emin aksoy, feray guven, mehmet erhan sayali, dilek kitapcioglu (2018) stated that the spre of experimental class is higher that control class, where the experimental class were givem web-based learning method, while control class with traditional learning method. This is supported also by the finding ofalexander el-ali md,farihakamal ba, c. Lynncabral md, judy h.squires md (2018) stated that students who finised web based module have higher average knowledge score than those who were given traditional learning material. 


\section{CONCLUSIONS AND SUGGESTIONS}

Based on the result of Web Learning based Ula-ula Lembing Dance Tutorial Video, the first meaning was seen from student who was sitting alone and contemplating for getting the knowledge they had never knew during school. And that is included in the meaning that the learning used made the students comfortable in learning. The visual meaning can be seen from picture taking process, color and design technique for learning media that can emerge the meaning of that web learning. For example, in good composition arrangementwith more meaning in it. Then from the pose, which everything is shows by gesture, some expression, that can impress other thing that what is seen. Especially, the tutorial video presented made students easier in mastering every move of Ula-Ula Lembing dance.

\section{REFERENCES}

[1] Abidin, Y. (2016). Desain sistem pembelajaran dalam konteks kurikulum 2013. Bandung: PT Refika Aditama.

[2] Ahmad Rivai, Nana Sudjana. Media Pengajaran. Bandung: Sinar Baru Algesindo.

[3] Anderson, L.W. dan Krathwohl, D.R. (2001). A Taxonomy for Learning, Teaching, and Asessing: A Revision of Bloom's Taxonomy of Educational Objectives. A Bridged Edition. New York: Addison Wesley Longman, Inc.

[4] Arsyad, A. (2014). Media pembelajaran. Jakarta: PT Rajagrafindo Persada.

[5] Arif S. Sadiman, dkk. (2014). Media pendidikan: pengertian, pengembangan dan pemanfaatannya. Depok: PT. Raja Grafindo Persada.

[6] Arikunto, S. (2009). Dasar-dasar evaluasi pendidikan. Jakarta: Bumi Aksara.

[7] Arikunto, S. (2010). Prosedur penelitian suatu pendekatan praktik. Jakarta: Rineka Cipta.

[8] Arikunto, S. (2012). Prosedur penelitian. Jakarta: Rineka Cipta.

[9] Arsyad, A. (2011). Media pembelajaran. Jakarta: PT Raja Grafindo Persada.

[10] Arsyad, A. (2016). Media pembelajaran. Jakarta: Raja Grafindo Persada

[11] Arum, Sekar Ing Pangestuti, Fajar Arianto. (2020), Media Video Pembelajaran Materi Ragam Gerak Tari Remo Gagrak Anyar Pada Mata Pelajaran Seni Budaya Kelas X Sman 19 Surabaya. Jurnal Mahasiswa Teknologi Pendidikan. 10(29). 1-9.
[12] Abidin, Y. (2016). Desain sistem pembelajaran dalam konteks kurikulum 2013. Bandung: PT Refika Aditama.

[13] Borg, W. R., \& Gall, M. D. (1983). Educational research: an introduction, Fifth edition. New York: Longman.

[14] Brunicardi F C, Anderson D, Dunn DL. 2005. Schwartz's Principles of surgery. 8 edition. New York: McGraw-Hill Medical Publishing. [9] A. Pnueli, In transition from global to modular temporal reasoning about programs, in: K.R. Apt (Ed.), Logics and Models of Concurrent Systems, Springer, Berlin, Heidelberg, 1984, pp. 123-144. DOI: https://doi.org/10.1007/978-3-642-82453-1_5 